\title{
Geochemical approaches in tsunami research: current knowledge and challenges
}

Tetsuya Shinozaki ${ }^{1,2^{*}}$

\begin{abstract}
Over the past decade or so, geochemical techniques have been applied to the study of modern and past tsunamis. Seawater incursions and the introduction of marine organic matter can be detected through geochemical analysis, providing strong evidence that an event deposit was formed by saltwater inundation. Furthermore, the marine geochemical signature of an event may reveal the full extent of tsunami inundation far more precisely than can be obtained from sediment alone. Based mainly on literature published during the last 4 years, this paper summarizes the latest advances in and some problems with tsunami geochemical research, and specifically addresses organic and inorganic proxies with high preservation potential, geochemical characteristics of invisible tsunami deposits, handling of data from core scanners, and offshore environmental impacts. Recent studies have proposed that some organic and inorganic geochemical proxies have high preservation potential, and sometimes such evidence can be recognized from invisible tsunami deposits. Quantitative assessments of biomarkers are also effective for detecting allochthonous materials. Organic and inorganic proxies can be applied both to identify tsunami deposits and to accurately reconstruct tsunami inundation areas; however, there are as yet no universal criteria for accurate reconstruction of tsunami inundation areas by detecting invisible tsunami deposits using geochemical approaches. For deeper understanding of the behavior of geochemical characteristics derived from tsunami events, additional knowledge of the geochemical substances associated with modern and paleo-tsunami events is required. Specifically, further work is required on assessment of the environmental selectivity of geochemical proxies and refinement of core-scanner analysis for both organic and inorganic substances.
\end{abstract}

Keywords: Tsunami, Tsunami deposits, Geochemical approach, Allochthonous materials, Organic geochemistry, Inorganic geochemistry

\section{Introduction}

Inundations of coastal regions by large tsunamis cause severe damage to human life, the coastal environment, and the alongshore topography. Tsunamis greatly erode the sea bottom, dunes, and terrestrial soil; consequently, sediments are widely deposited within the inundation area. The redeposited sediment contains crucial information on tsunami phenomena, such as the tsunami's magnitude and age. Although large amounts of information

\footnotetext{
*Correspondence: tetsuya.shinozaki@aist.go.jp

${ }^{2}$ Geological Survey of Japan, National Institute of Advanced Industrial Science and Technology (AIST), Higashi 1-1-1-C7, Tsukuba, Ibaraki 305-8567, Japan

Full list of author information is available at the end of the article
}

are available for modern tsunamis, such as sediment characteristics (e.g., distribution, thickness, and grain size) and observation data (e.g., flow velocity, water depth, and tidal level), knowledge limited to recent tsunamis is insufficient for understanding tsunami phenomena because large tsunamis are low-frequency events. Thus, research on historical and prehistoric as well as modern tsunamis is required.

Tsunami research is interdisciplinary in nature. Although primarily based on sedimentology, studies of tsunami deposits can also incorporate geological, paleontological, biological, geomorphological, archeological, contextual, and geochemical approaches (Goff et al. 
2012). Several independent lines of evidence may be needed to prove a tsunami origin for a deposit.

A geochemical approach was first applied to tsunami research by Minoura and Nakaya (1991). They collected lake-bottom sediment in which some event sand layers were intercalated with mud deposits. They found that the concentrations of some water-leachable ions $\left(\mathrm{K}^{+}\right.$, $\mathrm{Na}^{+}, \mathrm{Ca}^{2+}, \mathrm{Mg}^{2+}$, and $\mathrm{Cl}^{-}$) were increased in event layers and attributed the increase to seawater incursion by historical and prehistoric tsunamis. After Minoura and Nakaya (1991), geochemical analyses of historical and paleo-tsunami deposits have continued (e.g., Kumagai 1999; Chagué-Goff and Goff 1999; Chagué-Goff et al. 2002). After recent large tsunamis, such as the 2004 Indian Ocean tsunami, the 2009 South Pacific tsunami, the 2010 Maule tsunami, and the 2011 Tohoku-oki tsunami, studies of tsunami deposits dramatically increased and geochemical techniques became more widely applied. Research has been conducted on the geochemical characteristics of tsunami deposits (e.g., Srinivasalu et al. 2010; Chagué-Goff et al. 2012a, b, 2015; Yoshii et al. 2013), the temporal variation and preservation potential of tsunami deposits (Szczuciński et al. 2007; Chagué-Goff et al. 2012b; Shinozaki et al. 2016), the presence of geochemical features beyond the distribution limit of sandy tsunami deposits (Goto et al. 2011; Chagué-Goff et al. 2012a, 2015), application of new analytical techniques (Cuven et al. 2013; Kuwatani et al. 2014), and the use of biomarkers as new geochemical markers (Shinozaki et al. 2015; Szczuciński et al. 2016; Bellanova et al. 2020a, b).

In recent review papers, Chagué-Goff (2010) summarized the tool kit available for geochemical analysis, and Chagué-Goff et al. (2017) included almost all published tsunami geochemical papers worldwide as well as information on geochemical markers. Although Chagué-Goff et al. (2017) ably summarized the knowledge and limitations of geochemistry in tsunami research at the time of publication, many geochemical papers have been published in the ensuing 4 years and further knowledge has accumulated. This paper summarizes the current knowledge of and problems in geochemical approaches to tsunami research, based mainly on papers published after Chagué-Goff et al. (2017), and discuss directions for future investigation.

\section{Role of geochemistry in tsunami research}

The basic concept of tsunami geochemistry is to find evidence of tsunami incursions by detecting allochthonous materials that are transported from coastal regions (shallow sea areas, beaches, dunes, and coastal land) to terrestrial settings, and vice versa, by means of geochemical proxies (Fig. 1). Detection of allochthonous materials using geochemical proxies is widely performed in paleoenvironmental and climate research. Variations in the amounts of terrestrial organic matter in seafloor sediment reveal changes in river discharge that are related to climate change, for example in the Arctic Ocean (e.g., Stein and Fahl 2000) and East Asia (e.g., Zhao et al. 2017). Another example, abrupt ocean surface cooling events during the Holocene in the North Atlantic, i.e., ice-rafted debris events, were identified on the basis of variations in the amounts of terrestrial material, which was transported from land to the ocean by catastrophic discharge, present in seafloor sediment (Bond et al. 1997, 2001). To identify allochthonous material, it is sometimes necessary to detect different source materials. Naturally, such evidence must be preserved on a geological time scale. Finding and tracing allochthonous materials is a strength of geochemistry, as demonstrated by its application to tsunami research.

In onshore tsunami research, geochemistry is regarded as a means of identifying tsunami deposits because seawater incursion by a tsunami leaves behind geochemical evidence, for example salt, marine organisms, marine carbonates, and allochthonous heavy metals (Fig. 2). Geochemistry is focused on both the sedimentary deposit and chemical substances, such as seawater components and organic materials; therefore, geochemical techniques can be applied to identify a tsunami inundation area that lacks visible tsunami deposits (Goto et al. 2011; Chagué-Goff et al. 2012a, 2015) (Fig. 2). Although a thin, fine-grained tsunami deposit can be recognized if it was formed by a recent tsunami, as in the case of the 2011 Tohoku-oki tsunami (Chagué-Goff et al. 2012a; Szczuciński et al. 2012; Bellanova et al. 2020a), in general, it is difficult to determine a tsunami inundation limit from the existence of a visible tsunami deposit in geological layers. Near the inundation limit, tsunami deposits tend to be thin and fine-grained because the weakened tsunami flow cannot transport coarser particles and large amounts of sand; thus, tsunami deposits can be difficult to distinguish from underlying and overlying sediment by visual observation. Moreover, the presence of sediments derived from terrestrial areas can also cause difficulty in identifying event deposits. Underestimation of tsunami inundation limits leads to misunderstanding of the magnitudes of tsunami-generated earthquakes (Namegaya and Satake 2014). Thus, a geochemical approach that detects not sediment itself, but seawater incursion, facilitates reconstruction of the inundation area more accurately than is possible from the distribution of visible tsunami deposits.

It should be noted that the geochemical approach is only one means of identifying tsunami deposits. Geochemical proxies are not all-round tools; naturally, other methods should also be considered, for example 


\section{Normal environment}

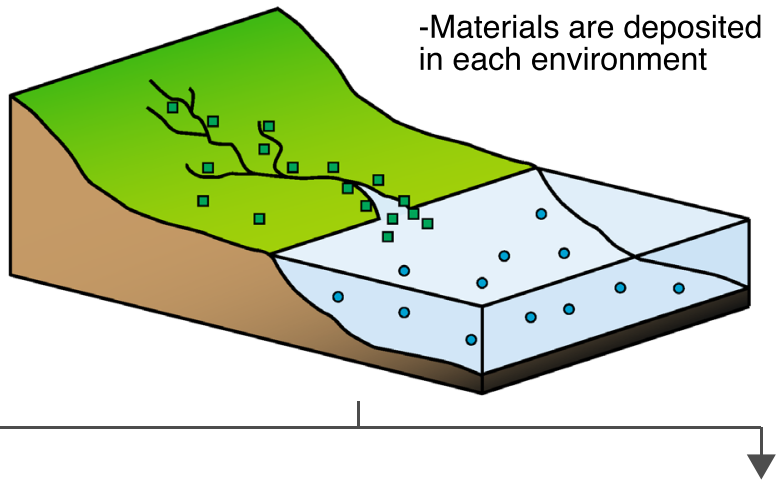

\section{Tsunami or storm inundation}

- Offshore materials are
transported onshore
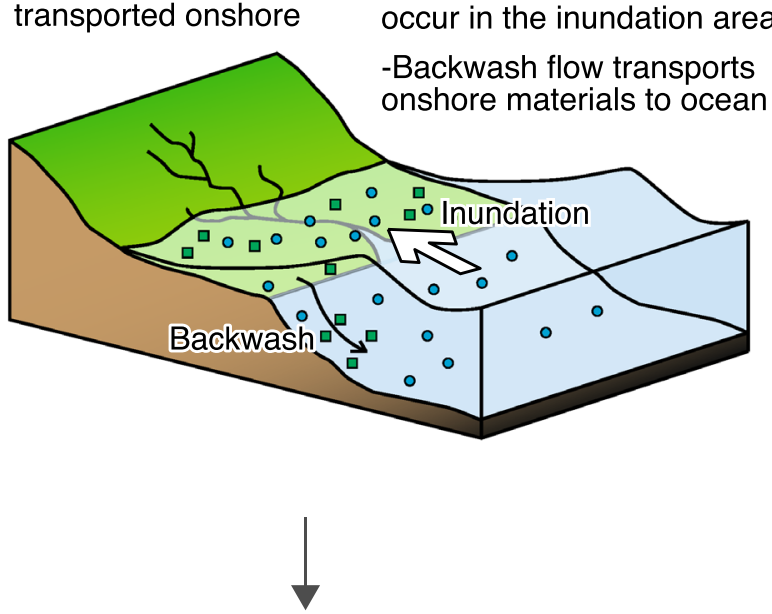

Onshore coring several years after the event

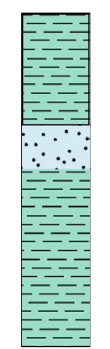

Original soil

(composed of terrestrial materials)

Tsunami deposits

(containing oceanic materials)

Original soil

(composed of terrestrial materials)

\section{Catastrophic discharge (flooding)}

- Onshore materials are -Allochthonous materials transported offshore are widely dispersed in the
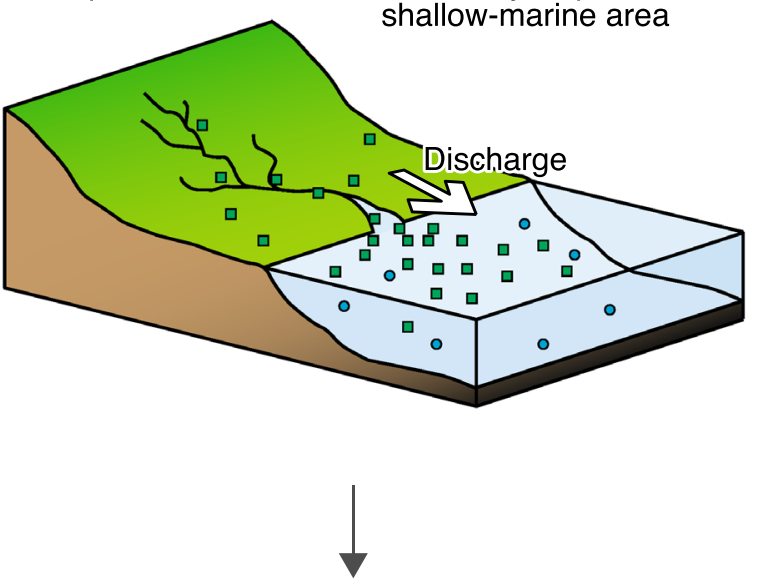

Offshore coring several years after the event

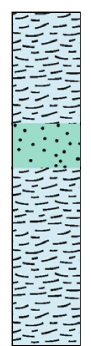

Original sea-bottom sediment (composed of oceanic materials)

Catastrophic discharge deposits (containing terrestrial materials)

Original sea-bottom sediment (composed of oceanic materials)

Fig. 1 Schematic diagram showing transportation of allochthonous materials. Green squares and blue circles indicate terrestrial and oceanic materials, respectively. Catastrophic events (e.g., tsunamis, storms, and flooding) cause transport of allochthonous materials; these materials become incorporated into the sedimentary record as event deposits

sedimentology and paleontology. Such multi-proxy studies will better ensure accurate identification of tsunami deposits. It should also be borne in mind that an absence of geochemical characteristics does not necessarily indicate that an event deposit is not a tsunami deposit (Dominey-Howes et al. 2006).

\section{Current knowledge and problems}

As summarized by Chagué-Goff et al. (2017), previous studies described geochemical behavior, including temporal changes, on the basis of modern tsunamis and the geochemical characteristics of paleo-tsunami deposits. The geochemical behavior of modern tsunamis is also 


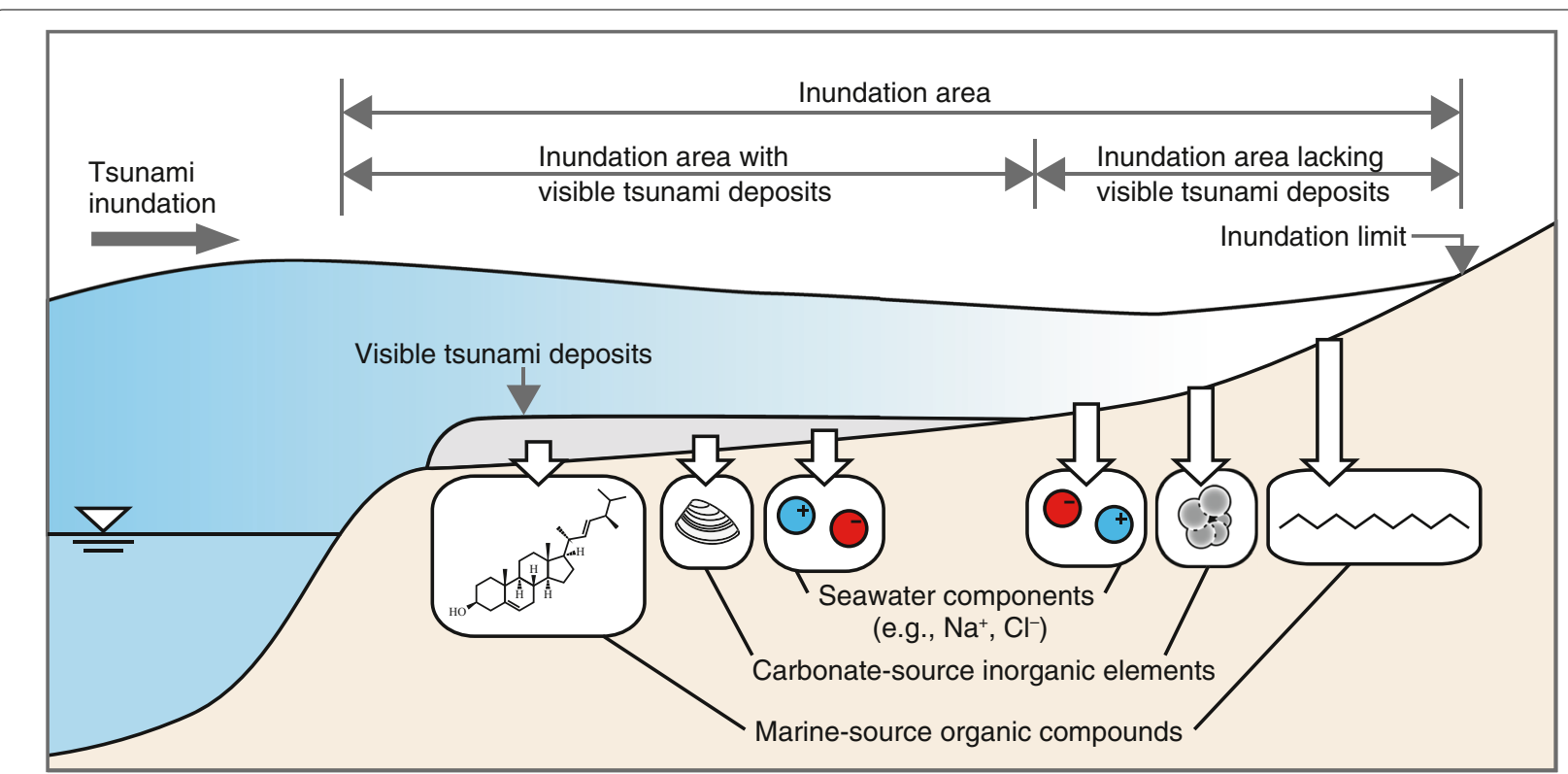

Fig. 2 Sedimentation and transportation by tsunami inundation. Tsunami deposits are not always deposited at the inundation limit; therefore, the inundation limit may be underestimated when considering only visible tsunami deposits. In contrast, geochemical signatures can be detected in both visible and invisible tsunami deposits because the signatures are derived from seawater incursion

of interest for environmental impact assessments (e.g., Komai et al. 2012; Chagué-Goff et al. 2012b). However, when applying a geochemical approach to paleo-tsunami research, such as identifying proxies or accurately reconstructing inundation areas, the state of preservation of geochemical characteristics is crucially important (Szczuciński 2020). For such applications, a persistent geochemical proxy is necessary. To reveal tsunami history, geochemical characteristics should be preserved in geological deposits on a time scale of 100 to 10,000 years. After incursion of a tsunami into a terrestrial area, several types of tsunami geochemical characteristics, such as $\mathrm{pH}$, electric conductivity, and ions, are preserved in the broad inundation area for periods of days to months; however, they may be lost with further passage of time, especially in tropical and temperate regions. In the case of the 2004 Indian Ocean tsunami, the levels of water-soluble salts in tsunami deposits on land were strongly reduced after the rainy season (Szczuciński et al. 2007). The high electric conductivity resulting from the tsunami was also diluted by rainfall (Nakaya et al. 2010). Chandrasekharan et al. (2008) reported reduced values of electric conductivity and $\mathrm{pH} 6$ months after the tsunami, although the ground-water was still highly saline. In the case of the 2011 Tohoku-oki tsunami, high concentrations of waterleachable ions derived from the tsunami incursion were detected a few months after the event, although these higher concentrations were no longer present a few years later (Chagué-Goff et al. 2012b; Shinozaki et al. 2016).
The rapid dilution of water-soluble materials by meteoric water means that these proxies cannot be applied to paleo-tsunami deposits. However, some geochemical substances, for example sulfur (Chagué-Goff et al. 2002; Fruergaard et al. 2015) and biomarkers (Alpar et al. 2012; Ünlü et al. 2012), appear to have high preservation potential.

Below, recent studies (published after 2017) are briefly summarized. These papers can be categorized into four topics: organic and inorganic proxies with high preservation potential; the geochemical characteristics of invisible tsunami deposits; handling of data from core scanners; and offshore environmental impacts. Based on these categories, current trends in tsunami geochemistry are identified.

\section{Organic and inorganic proxies with high preservation potential}

Studies published after that of Chagué-Goff et al. (2017) have described the geochemical characteristics of modern tsunamis, including several that applied proxies with high preservation potential. Two recent studies indicate that organic geochemical substances have high preservation potential. Bellanova et al. (2020b) investigated anthropogenic substances (polycyclic aromatic hydrocarbons, pesticides, and organochlorides) in far-field tsunami deposits in the Kahana Valley, O'ahu, Hawai'i. The detection of such compounds in or just below a historical tsunami deposit suggests the potential of this approach 
to identify tsunami deposits. Bellanova et al. (2020a) documented biomarkers and anthropogenic markers in tsunami deposits left by the 2011 Tohoku-oki tsunami on the Sendai Plain, Japan, and found that their concentrations differed significantly between pre- and posttsunami deposits. They concluded that anthropogenic markers and biomarkers have the potential to be a valuable proxy for tsunami research due to their high source specificity and relatively good preservation potential. These studies indicated the potential of anthropogenic markers and biomarkers for tsunami research, although anthropogenic markers may not be applicable to prehistoric tsunami deposits.

Bellanova et al. (2020a, b) revived consideration of the preservation potential of biomarkers, as suggested by some previous studies (Alpar et al. 2012; Shinozaki et al. 2015); in addition, they further explored quantitative assessment of allochthonous biomarkers. Detection of aquatic/marine biomarkers has been attempted (Alpar et al. 2012; Shinozaki et al. 2015, 2016), with varying degrees of success; in some cases, aquatic/marine biomarkers could not be recognized in known tsunami deposits or the underlying layer. Another approach has involved comparison of the concentrations of terrigenous and aquatic/marine biomarkers (Bellanova et al. 2020a, b). Three ratios, the terrigenous-to-aquatic ratio (TAR), the carbon preference index (CPI), and the odd-to-evenpredominance ratio (OEP), were applied to demonstrate dominance of terrestrial plants or marine organisms, and to ascertain the biogenic or petrogenic origin of $n$-alkanes in sediments (Bellanova et al. 2020a). In terrestrial areas, especially those further inland, it is difficult to identify tsunami deposits because the contribution of terrigenous organic matter is larger than in sites near the coast. Even in such cases, quantitative assessments such as those carried out by Bellanova et al. $(2020 \mathrm{a}, \mathrm{b})$ could be used to detect allochthonous organic materials. In the future, quantitative assessment of biomarkers could be applied to paleo-tsunami research.

Inorganic geochemical proxies also have been studied in historical and prehistoric tsunami deposits (Judd et al. 2017; Moreira et al. 2017; Chagué et al. 2018, 2020; Avşar 2019; Watanabe et al. 2020). Judd et al. (2017) and Chagué et al. (2018) characterized recent (within 100 years) tsunami deposits by geochemical proxies. Judd et al. (2017) identified evidence of small historical tsunamis in Lyttelton Harbour, New Zealand, using sedimentological, geochemical, and diatom analyses. They found that the amounts of certain geochemical markers, e.g., normalized $\mathrm{Ca}, \mathrm{K}, \mathrm{Si}$, and $\mathrm{Sr}$, were increased in some levels that also exhibited lower organic-matter content and magnetic susceptibility, and variations in diatom assemblages. Notably, these characteristics were detected despite atypical sedimentary evidence (no sand) or a lack of sediment. That study demonstrated that multi-proxy evidence, including inorganic geochemistry, can be used to distinguish faint or invisible tsunami deposits, and these characteristics can be preserved for small tsunamis. Chagué et al. (2018) identified and distinguished sediment sources based on a combination of the geochemical signature and grain-size characteristics. They found that deposits from the 1946 and possibly 1960 tsunamis in Hawaii are coarse-grained units containing peat and soil sediments. The lower unit is characterized by high $\mathrm{Mn}$, $\mathrm{Fe}, \mathrm{Rb}, \mathrm{La}$, and Ce counts, as well as elevated magnetic susceptibility. This unit consists of very poorly sorted, brown muddy and sandy sediment including sub-angular gravel clasts of weathered basalt fragments. Because this layer does not contain any of the black volcanic sand that is present on the beach, they discounted the beach as a sediment source. They concluded that the unit could be attributed to a flood event, most probably a tropical storm. In contrast, the upper unit is composed of finegrained volcanic sand and fine silt and is characterized by the appearance of As, Ca, and Sr. These characteristics suggest that the unit was derived from a marine or estuarine source. In tsunami research, identification of sediment sources is challenging (e.g., Morton et al. 2007). Distinction of a sediment source based on the combination of geochemical signatures and grain-size characteristics, as demonstrated by Chagué et al. (2018), can be applied to other sites.

Other studies have described the geochemical characteristics of older tsunami deposits. Moreira et al. (2017) determined the geochemical characteristics of a tsunami deposit formed by the 1755 Lisbon tsunami by analyzing sediment core samples collected in a lagoon on the south coast of Portugal (Costa et al. 2012). The tsunami deposit was enriched in bioclasts (exhibiting high $\mathrm{Si} / \mathrm{Al}$ and $\mathrm{Ca} /$ Ti values) compared to the underlying and overlying mud layers. Moreover, geochemical salinity indicators, such as $\mathrm{Cl}$ and $\mathrm{Br}$, were detected beyond the sandy sedimentological signatures. These results indicate that evidence of marine inundation continued beyond the extent of the tsunami deposit and was preserved for at least 250 years in a lagoonal succession. Avşar (2019) presented geochemical evidence of historical tsunamis in the Eastern Mediterranean for the last 700 years detected in the sedimentary sequence of Oludeniz Lagoon, southwest Turkey. Three event deposits that were enriched in $\mathrm{K}, \mathrm{Ti}$, $\mathrm{Fe}$, and $\mathrm{Zn}$ but depleted in Ca were attributed to a sudden increase in the input of terrigenous sediment to the lagoon. This paper is notable for its focus not on seawater components, but on terrigenous input. Watanabe et al. (2020) examined modern and paleo-tsunami deposits on the Pacific coast of northeast Japan and found that the 
$\mathrm{Na} / \mathrm{Ti}$ atomic ratios were markedly higher in two paleotsunami deposits (Jogan, 1080 calibrated age before present [cal BP], and Yayoi, $2000 \mathrm{cal} \mathrm{BP).} \mathrm{They} \mathrm{con-}$ cluded that $\mathrm{Na} / \mathrm{Ti}$ ratios are a useful proxy for identifying tsunami deposits. They also found that geochemical evidence can be preserved over long time scales. Such geochemical evidence may be applicable to paleo-tsunami deposits at other sites. Chagué et al. (2020) compiled a 7300-year record of long- and short-term environmental changes in a coastal wetland in New Zealand by analysis of sedimentological, geochemical, diatom, and geochronological data from three sediment cores. They found that more than one tsunami had affected the area in the last 3000 years, and detected a tsunami geochemical signature (Ca and $\mathrm{S}$ ), but no clear sedimentological signature, in a sediment core from the middle of the wetland. A contemporaneous geochemical marine signature was not detected further inland. This paper is notable because finding an evidence of seawater inundation in the absence of sedimentary deposits is ideal for tsunami geochemistry.

As described above, research on application of inorganic geochemical proxies to tsunami deposits has continued since the review of Chagué-Goff et al. (2017). These recent papers applied proxies that appear to possess high preservation potential. These proxies may yield improved understanding of tsunami-deposit geochemical characteristics and facilitate identification of paleotsunami deposits and detection of inundation areas that lack visible tsunami deposits. Furthermore, inorganic substances have been more commonly analyzed than organic substances, because analysis of inorganic compounds is much simpler. In particular, organic (biomarker) analysis requires time-consuming pre-treatment of samples and various specific pieces of equipment, and therefore analytical opportunities are more limited. However, biomarker analysis is a powerful method because it allows unambiguous detection of allochthonous materials. Inorganic proxies are sometimes difficult to identify in tsunami deposits because they exist in both terrestrial and marine environments (although in markedly different quantities) and onshore tsunami deposits consist of mixtures of terrestrial and oceanic materials. In contrast, a strength of organic geochemistry is identification of marine compounds that do not exist in the terrestrial environment. The presence of marine compounds in onshore deposits can be strong evidence for seawater incursion.

No previous studies have analyzed both organic and inorganic substances in the same core sediment. Detection of seawater incursion by means of geochemical proxies appears to be widely applicable because the source materials do not affect the evidence and seawater components or marine organisms are always present in seawater; however, the behavior of a given proxy is not always consistent. The preserved characteristics of tsunami deposits may be affected by local conditions. In the future, the environmental selectivity of each geochemical proxy should be elucidated on the basis of multiple analyses of single sediment cores.

\section{Geochemical characteristics of invisible tsunami deposits}

Non-visible evidence of a tsunami is useful for both reestimation of inundation limits and correct reconstruction of tsunami recurrence intervals. Even if a tsunami has occurred, a tsunami deposit may not have been generated: for example, small tsunamis cannot transport large amounts of sediment, and a tsunami cannot leave a sandy tsunami deposit if there is no source of sand. Detection of such invisible tsunami evidence can allow reconstruction of the accurate tsunami history for a specific area.

Geochemical work has been carried out on invisible tsunami deposits for recent tsunamis: the 2011 Tohokuoki tsunami (Goto et al. 2011; Chagué-Goff et al. 2012a) and the 2010 Maule tsunami (Chagué-Goff et al. 2015). In addition, Watanabe et al. (2020) carried out inorganic analysis and mentioned the possibility of applying geochemical proxies (e.g., the $\mathrm{Na} / \mathrm{Ti}$ ratio) to detect muddy tsunami deposits close to the limit of inundation. However, detection of geochemical evidence near the inundation limit is difficult because the contribution of terrestrial materials increases inland.

Although few invisible records from historical and prehistoric tsunami deposits have been documented, some recent studies described the geochemical characteristics of historical and prehistoric tsunamis in the absence of sedimentary evidence and in areas beyond sandy tsunami deposits (Judd et al. 2017; Moreira et al. 2017; Chagué et al. 2020). In addition, use of computed tomography (CT) images and grain-size analysis allowed identification of three historical tsunami deposits in southeastern Hokkaido, Japan (Shinozaki et al. 2020). These tsunamis were recorded in historical documents but had not previously been detected in the geological record. Moreover, one of these tsunami deposits had distinctive geochemical characteristics: the concentration of $\mathrm{Ca}^{2+}$, which is a major component of seawater, decreased downward through a tsunami deposit layer and increased beneath the layer. This $\mathrm{Ca}^{2+}$ distribution may have formed because seawater components can penetrate a sandy tsunami deposit, owing to its porosity being higher than that of a muddy layer, and thus became concentrated beneath the tsunami deposits. This pattern has also been observed in terrestrial regions (e.g., Chagué-Goff et al. 2012b; Shinozaki et al. 2016). Although it should be noted that Shinozaki 
et al. (2020) detected invisible tsunami deposits on the basis of CT images and grain-size distribution, not geochemical data, the fact that geochemical trends relevant to tsunami deposits were observed mean that such trends could be applied to identify invisible tsunami deposits.

However, distinctive geochemical evidence was not detected from the other two historical tsunami deposits (Shinozaki et al. 2020). Preservation potential does not seem to be not a factor, because evidence was detected from the deepest event layer of the three, i.e., from the oldest tsunami event. Although the amount of seawater carried by a tsunami may influence the geochemical characteristics, the specific factors involved are unclear. Geochemical characteristics, in this case seawater components, are considered to be a useful tool in tsunami research; however, a good understanding of their behavior based on an accumulation of case studies is required.

Because deposits left by paleo-tsunami events may have been affected by disturbance from plant roots or contamination by terrestrial organic matter, which may destroy geochemical evidence, improved means of finding invisible evidence effectively are necessary. In the future, these proxies could be applied to reveal the detailed distribution of non-obvious deposits from paleo-tsunami events. Continued research may find additional examples of persistent proxies. The important point is that our understanding of geochemical characteristics has improved for both recent and paleo-tsunami deposits.

\section{Handling of data from core scanners}

An X-ray fluorescence (XRF) core scanner can be applied to identify tsunami and storm deposits (e.g., Judd et al. 2017; Moreira et al. 2017; Chagué et al. 2018, 2020; Pouzet et al. 2018; Avșar 2019). Core scanners have the advantages that analysis can be performed without sample destruction and large amounts of data can easily be obtained in high resolution (1-2 $\mathrm{mm}$ thickness).

Although the XRF core scanner is a markedly useful method for sediment cores, factors such as water content, amount of organic matter, grain-size variation, and surface roughness can influence XRF measurements (Croudace et al. 2006; Böning et al. 2007; Tjallingii et al. 2007; Hennekam and de Lange 2012; Chawchai et al. 2016). The effects of sample inhomogeneity and surface roughness are particularly pronounced for sediment containing abundant particles of medium to coarse sand size (Richter et al. 2006). For example, Jansen et al. (1998) reported that heterogeneities caused by water content, porosity, grain-size variation, and surface roughness led to bias in the scanner data, which are commonly of the order of $\sim 200$ counts per second (cps), at the $2000 \mathrm{cps}$ level. Core samples of tsunami deposits have rough surfaces because they commonly contain sand particles, shell fragments, and undecomposed plant fragments, meaning that the effect of sample inhomogeneity can be particularly pronounced. Moreover, lighter elements, for example $\mathrm{Ca}$, that emit fluorescence at lower intensities with more scatter are more sensitive to sample heterogeneity than are heavier elements that emit relatively high fluorescence intensities with less scatter (Richter et al. 2006; Weltje and Tjallingii 2008; Chawchai et al. 2016). In tsunami research, $\mathrm{Ca}$ is an important element because it is a proxy of seawater or carbonate; therefore, the effect of surface roughness on XRF measurements should be considered.

If analysis is conducted with a core scanner, the correlation between XRF data from the core scanner and conventional XRF data obtained from analysis of individual layers must be assessed. Chagué et al. (2020) applied inductively coupled plasma atomic emission spectrometry (ICP-AES) and ICP mass spectrometry (ICP-MS) to analyze several elements in specific layers, in addition to performing a high-resolution continuous XRF core scan. Although they did not attempt to quantify the core scan data based on the ICP-AES and ICP-MS data, nor did they attempt to verify those data, their study is valuable because comparison of scan data and conventional data for individual layers was possible. Although Chagué-Goff et al. (2012a) did not use a core scanner, they reported that measurements of water-leachable chloride and sulfate obtained with a portable XRF unit were strongly correlated with those from ion chromatography. For the case of sea-bottom sediment, Hennekam and de Lange (2012) compared XRF scanning data with two conventional methods, XRF with beads and ICP optical emission spectrometry (ICP-OES). The XRF scan data were reasonably consistent with those obtained from conventional methods for most elements, although deviations occurred in layers attributed to major paleoceanographic events. The deviations appear to have been related to the water content and distribution. In the future, such comparative research on heterogeneous core sediments (including sandy tsunami deposits, organic materials, and shell fragments) should be conducted.

\section{Offshore environmental impacts}

Research on offshore tsunami deposits is rare because of the difficulty in collecting cores and identifying tsunami deposits. Even so, some studies were conducted after the 2004 Indian Ocean tsunami (e.g., Srinivasalu et al. 2010; Sakuna et al. 2012) and the 2011 Tohoku-oki event (e.g., Ikehara et al. 2014; Toyofuku et al. 2014). There have been no recent studies (after the review of Chagué-Goff et al. 2017) considering the geochemical characteristics of offshore tsunami deposits. However, there has been some research on the application of geochemistry to 
oceanic environments, which can reveal the offshore geochemical behavior of tsunami events. This research can help to elucidate the geochemical characteristics of offshore tsunami deposits.

Nakamura et al. (2018) reported on the concentrations of oil and hydrocarbons in seabed sediments derived from tsunami-spilled oil in Kesennuma Bay, northeastern Japan. They collected sediment samples at 40 sites from 2012 to 2014. High concentrations of $n$-hexane extract, total petroleum hydrocarbons, and polycyclic aromatic hydrocarbons derived from spilled oil were detected. Moreover, they reported that approximately $13 \%$ of the amount of spilled oil was still present in the sediment of Kesennuma Bay in December 2014. Although that study focused on marine pollution, rather than tsunami research, the distribution of oil-derived hydrocarbons can be useful for understanding offshore tsunami deposits. Moreover, organic geochemistry may be applicable to offshore paleo-tsunami deposits given the high preservation potential of biomarkers and anthropogenic markers (Shinozaki et al. 2015; Bellanova et al. 2020a, b).

Ota et al. (2019) reported the sedimentary data and geochemical properties (total organic carbon, total nitrogen, total sulfur, and trace elements) of seafloor sediment collected in Matsushima Bay, northeastern Japan. They compared sediment data obtained before the 2011 Tohoku-oki tsunami and over a 5-year period after the tsunami. They found that the correlation between total organic carbon and total nitrogen contents increased after the tsunami, suggesting the occurrence of resuspension and mixing of organic matter in the surface sediments by the tsunami. The trace-element compositions of the sedimentary core samples suggest few or no changes in the sediment sources from before to after the tsunami. This study is notable because they compared seafloor sediments before and after the tsunami event. Moreover, they tracked the post-tsunami restoration behavior by measuring temporal changes.

Recent offshore research has focused on marine environmental changes rather than the characteristics of offshore tsunami deposits. As with research on environmental impacts onshore, understanding of marine environmental changes caused by tsunami events can be applied to identify tsunami deposits within seafloor sediment. The focus of onshore tsunami research is typically within the inundation area because the influence of seawater incursion is limited to that area. In contrast, in offshore areas, materials of terrestrial origin (particles and dissolved materials) transported from the land to the sea by backwash can spread in the oceanic area. Therefore, coring at several points within a broad area is desirable to understand oceanic environmental changes, even though such surveys are more difficult than those conducted onshore. However, offshore research also has advantages. Surface onshore sediments in coastal areas may be lost by land development or cannot be drilled; in addition, tsunami deposits formed by recent tsunamis may be removed as part of remediation. In contrast, humans do not generally remove tsunami-derived sediment in marine areas because it is not practicable. Although wellpreserved locations with an absence of bioturbation are necessary for studies of offshore tsunami deposits, development of such offshore research is desirable.

\section{Advances in tsunami geochemistry}

Although continued studies of the geochemical characteristics of modern and paleo-tsunami deposits are important, other approaches in addition to case studies are required to solve the problems in tsunami geochemistry described above. This section describes the types of research that are required to achieve a deeper understanding of tsunami geochemistry.

\section{Suitable proxies for identification of tsunami deposits}

To find additional geochemical proxies that are suitable for identification of tsunami deposits, it is necessary to determine which substances can be preserved for a long time (on the order of 100-10,000 years) in the geological record. One approach is longitudinal studies that measure temporal changes of geochemical parameters in recent tsunami deposits, relying on organic, inorganic, and isotopic geochemistry as well as sedimentological features. It is also important to include meteorological data, because annual rainfall influences ground-water movement. Because meteoric water seriously affects the preservation of geochemical characteristics, temporal changes may differ in different climatic areas. Initial selection of study localities should be carried out carefully: because the aim of such research is to reveal the temporal changes of geochemical as well as sedimentological characteristics, coastal areas with abandoned or waste land should be selected.

Another way to find suitable geochemical proxies is by carrying out geochemical analyses of paleo-tsunami deposits that are confidently identified on the basis of other evidence. High-resolution geochemical analysis of the paleo-tsunami deposit itself and the underlying and overlying soil is recommended. Geochemical evidence is sometimes sparse, especially in the case of organic geochemistry, because the contribution of terrestrial organic matter is much larger than the marine input (Shinozaki et al. 2015); therefore, evidence may be overlooked if analyses are conducted with low stratigraphic resolution. For example, Shinozaki et al. (2020) conducted analyses of water-leachable ions at $0.5-\mathrm{cm}$ sampling intervals and proposed that characteristic $\mathrm{Ca}^{2+}$ distribution was 
associated with tsunami incursion. If the analysis had been conducted with low resolution, this pattern might have been overlooked. Although appropriate sampling intervals depend on, for example, the sample type and sedimentation rate, studies that attempt to apply geochemical proxies to unidentified event deposits at low resolution risk confusing natural differences in sediment composition with the geochemical effects of tsunamis. First, proxies with a high preservation potential should be sought in modern tsunami deposits; subsequently, they can be applied to paleo-tsunami deposits as well as the overlying and underlying soil. This procedure will ensure that suitable proxies for identification of tsunami deposits can be identified.

Infiltration experiments may be effective to understand the behavior of geochemical characteristics; specifically, the length of time that the influence of tsunami inundation persists and the kinds of proxies that are preserved. In reality, observation of the temporal changes of geochemical characteristics is difficult because tsunami events are infrequent, and because tsunami deposits can be removed as part of restoration in many situations. Therefore, analogue experiments in which several factors are controlled (e.g., soil type, event deposit type, and amount of mixing of seawater and event deposits) are effective to understand geochemical characteristics. A simple example of an infiltration experiment is as follows (Fig. 3): first, standard soil that is similar in composition to that of the actual environment is prepared. Fundamental geochemical data are measured at various soil depths. After application of a known amount of sand and seawater spray, geochemical parameters are regularly measured at each depth at suitable time intervals. The results may reveal the temporal and spatial behavior of geochemical substances. Although this is just a simple case, more complex experiments could be conducted to assess the influence of specific features, such as a mud cap, rainfall, disturbance by vegetation, and different soil types. This type of study is best carried out in agricultural settings at the meter scale, allowing experimentation in the natural environment and incorporation of meteorological data.

\section{Accurate reconstruction of inundation limits}

Because geochemical characteristics can be detected in muddy tsunami deposits beyond the distribution limit of sandy tsunami deposits (Goto et al. 2011; Chagué-Goff et al. 2012a), geochemical approaches could be applied to reconstruct tsunami inundation limits more accurately. Identification of muddy tsunami deposits in the sedimentary record is still difficult, although some recent studies have reported invisible tsunami deposits on the basis of multi-proxy evidence (Judd et al. 2017; Shinozaki et al. 2020). First, to apply geochemistry to a muddy tsunami deposit, modern tsunami deposits and proxies with good preservation potential should be considered. Various geochemical proxies should be measured to identify the geochemical characteristics of muddy tsunami deposits. When applying organic geochemical proxies, such as the carbon/nitrogen $(\mathrm{C} / \mathrm{N})$ ratio and biomarkers, careful analytical technique is important. Because tsunami deposits contain mixtures of terrestrial and marine organic matter, the contribution of terrestrial material typically exceeds the marine contribution (Shinozaki et al. 2016), and marine organic matter may be masked by the

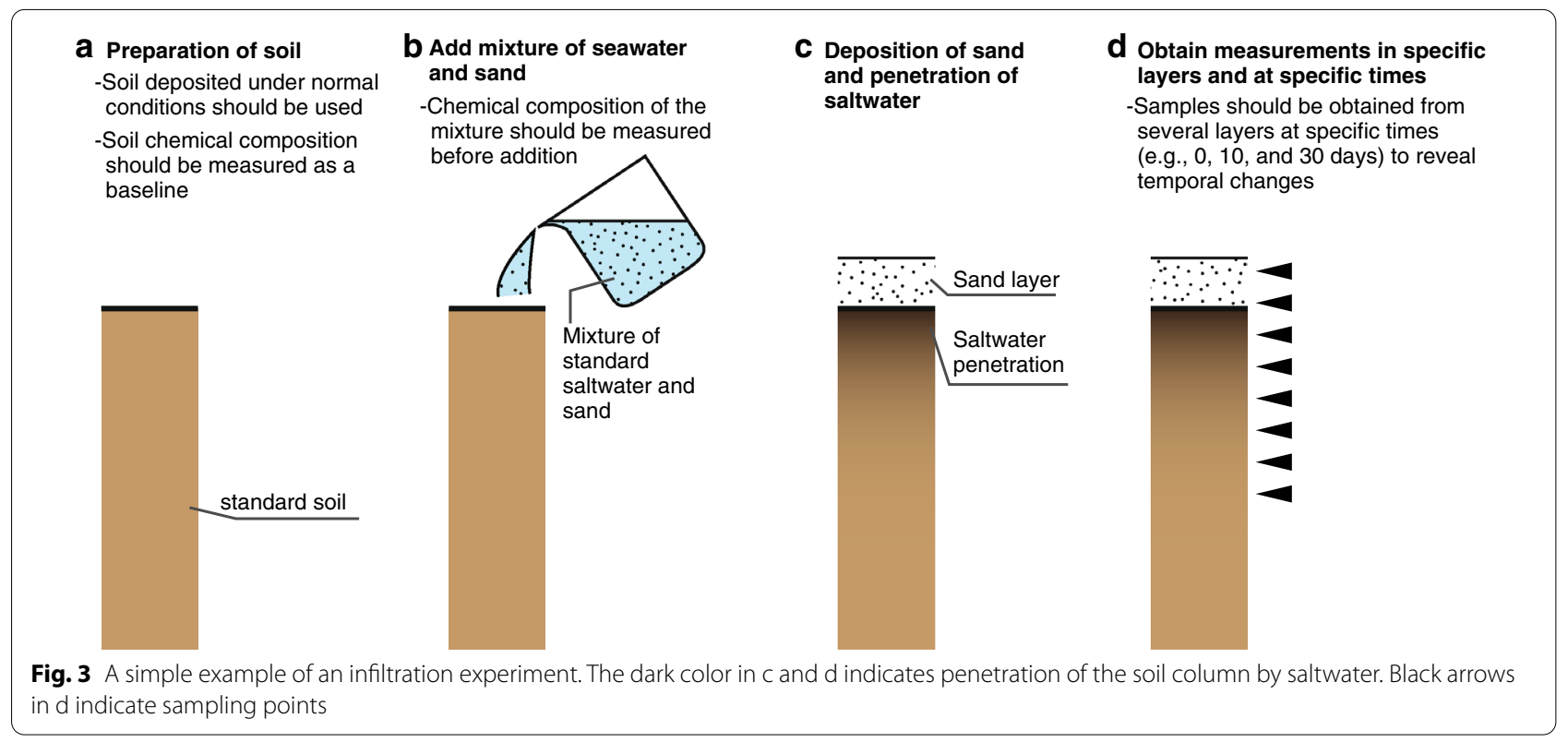


relatively large terrestrial component. Better results may be obtained after pretreating samples, for example by picking out plant fragments under a microscope or filtering while avoiding organic contamination.

Geochemistry should be applied to paleo-tsunami deposits after further geochemical analyses of modern tsunami deposits, such as sampling on transects across coastlines and collecting sediment beyond the limit of sandy tsunami deposits in selected locations (Fig. 4). In high-resolution analysis of the depth distributions of geochemical substances, distinctive values may represent an incursion of seawater (Fig. 4). Although such work will be difficult, accurate reconstruction of inundation areas will support improved estimates of the magnitudes of tsunamis and tsunami-generated earthquakes.

\section{Multidisciplinary research}

In the future, multidisciplinary research will be required for deeper understanding of the geochemical behavior of tsunami deposits. Pedology may reveal where inundated seawater components become concentrated. In general, soil particles that are negatively charged bind cations (such as $\mathrm{Ca}^{2+}, \mathrm{Mg}^{2+}, \mathrm{K}^{+}, \mathrm{Na}^{+}$, and $\mathrm{NH}_{4}^{+}$), and the amount of cations they can retain (the cation exchange capacity) is greater in clay- and organic-rich soil than in sand-rich and organic-poor soil (Parfitt et al. 1995; Robertson et al. 1999). Previous studies of tsunami deposits have shown that cations derived from seawater are concentrated in finer-grained and organic-rich layers, not in sandy tsunami deposits (Chagué-Goff et al. 2012b; Shinozaki et al. 2016). Biology may be able to clarify the influence of bioturbation on the preservation potential of substances that may serve as tsunami deposit proxies; thus, understanding the influence of bioturbation and decomposition is crucial. In addition, information is needed on how specific compounds, such as biomarkers and DNA, may be preserved. Hydrology may clarify ground-water movement in various soil types. Because geochemical characteristics can be diluted by meteoric water (e.g., Szczuciński et al. 2007), knowledge of ground-water movement is important for understanding the preservation of geochemical substances.

In tsunami research, geochemistry is one approach that can be applied to identify tsunami deposits; however, input from different research fields is necessary to interpret the behavior of geochemical substances. Researchers on tsunami geochemistry should seek collaborators from other research fields; this is a "royal road" to understanding geochemical behavior.

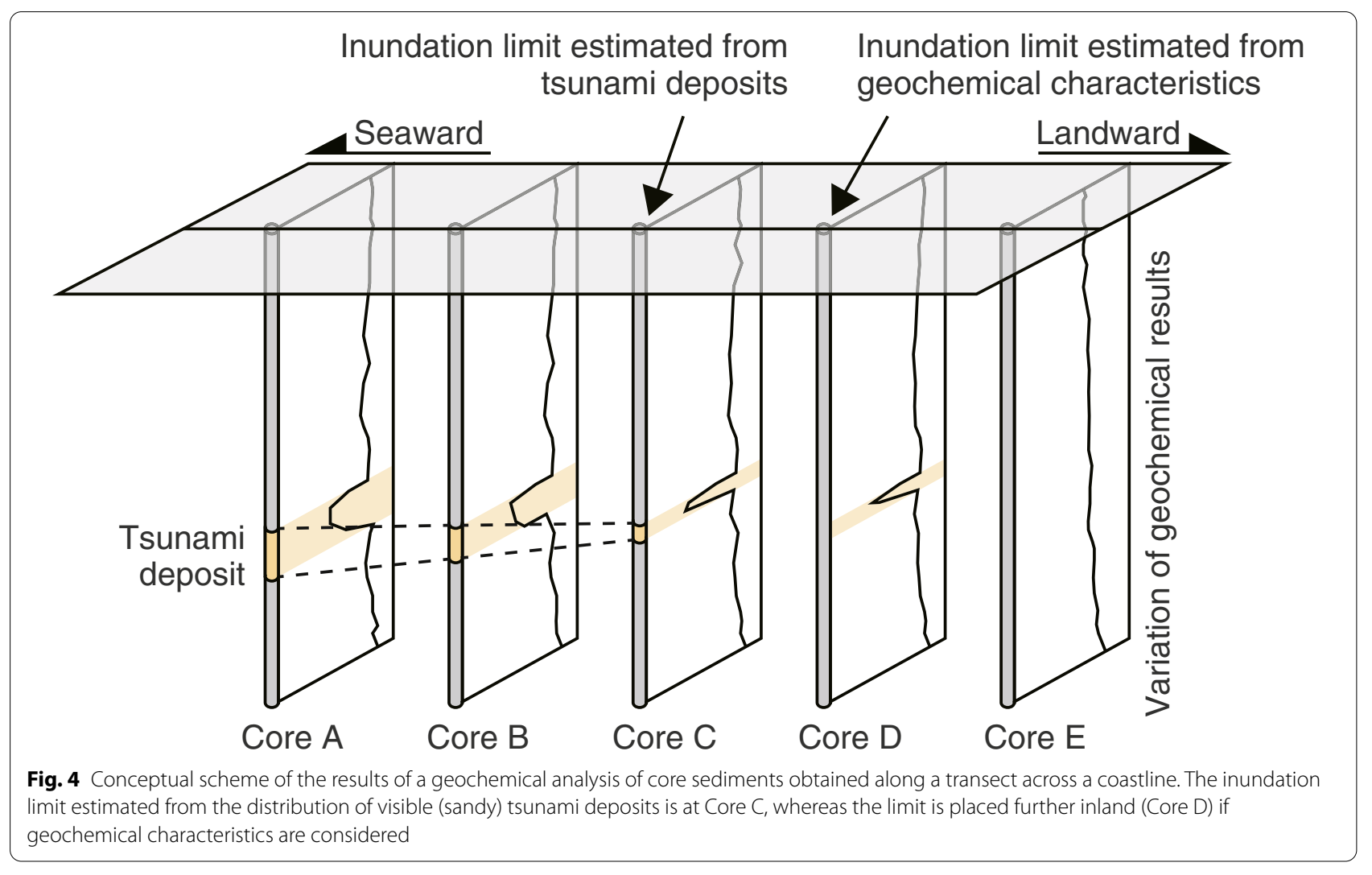




\section{Conclusions}

To date, the geochemical approach has been an effective tool in research on tsunami deposits, especially in identifying proxies for tsunami deposits. Recent studies have gradually increased our knowledge of the geochemical characteristics of tsunami deposits, and have also made clear that some serious problems exist. Merely conducting geochemical analyses on tsunami deposits is insufficient, and the discipline of tsunami geochemistry will be hampered the longer these problems are not addressed. Conversely, the study of tsunami geochemistry will be strengthened if evidence of tsunami inundation by means of geochemical proxies and accurate reconstruction of tsunami inundation areas can be achieved. Recent studies have identified proxies with high preservation potential, both organic and inorganic. Moreover, geochemical evidence can sometimes be obtained from invisible tsunami deposits. Tsunami geochemistry is a young specialty; therefore, it is natural that the field is experiencing some issues. It is important to keep addressing these issues in a careful manner.

Continuing to describe the geochemical characteristics of tsunami deposits is vital. In addition to this fundamental analysis, investigation of the geochemical behavior and preservation potential of more substances is necessary. Both positive and negative results are valuable and should be reported. Researchers in related fields may be able to add insights, and there may be improvements in analytical techniques. Tsunami geochemistry, which is a young research field, requires further accumulation of knowledge for future development.

\section{Acknowledgements \\ I thank Kazuhisa Goto, James Goff, and Kenji Satake (the editor-in-chief of Geo- science Letters) for providing me with the opportunity to write this paper. I am grateful to Anawat Suppasri for kindly editing this manuscript. I deeply thank two anonymous reviewers for their constructive comments, and Catherine Chagué for providing valuable comments prior to initial submission.}

\section{Authors' contributions}

TS was entirely responsible for the research for this study and wrote the manuscript. The author read and approved the final manuscript.

\section{Funding}

This research was supported by research funding from JSPS KAKENHI, Grant Number $20 J 00423$

\section{Availability of data and materials}

This paper has no original data.

\section{Declarations}

\section{Competing interests}

The author declares no competing interest.

\section{Author details}

${ }^{1}$ Center for Research in Isotopes and Environmental Dynamics (CRiED), University of Tsukuba, Tennodai 1-1-1, Tsukuba, Ibaraki 305-8577, Japan.

${ }^{2}$ Geological Survey of Japan, National Institute of Advanced Industrial Science and Technology (AIST), Higashi 1-1-1-C7, Tsukuba, Ibaraki 305-8567, Japan.
Received: 18 February 2020 Accepted: 27 February 2021

Published online: 06 March 2021

\section{References}

Alpar B, Ünlü S, Altınok Y, Özer N, Aksu A (2012) New approaches in assessment of tsunami deposits in Dalaman (SW Turkey). Nat Hazards 60(1):27-41. https://doi.org/10.1007/s11069-011-9951-0

Avşar U (2019) Sedimentary geochemical evidence of historical tsunamis in the Eastern Mediterranean from Ölüdeniz Lagoon, SW Turkey. J Paleolimnol 61:373-385

Bellanova P, Frenken M, Reicherter K, Jaffe B, Szczuciński W, Schwarzbauer J (2020a) Anthropogenic pollutants and biomarkers for the identification of 2011 Tohoku-oki tsunami deposits (Japan). Mar Geol 422:106117. https //doi.org/10.1016/j.margeo.2020.106117

Bellanova P, Frenken M, Richmond B, Schwarzbauer J, Selle SL, Griswold F, Jaffe B, Nelson A, Reicherter K (2020b) Organic geochemical investigation of far-field tsunami deposits of the Kahana Valley, O'ahu, Hawai'i. Sedimentology 67:1230-1248. https://doi.org/10.1111/sed.12583

Bond G, Showers W, Cheseby M, Lotti R, Almasi P, deMenocal P, Priore P, Cullen H, Hajdas I, Bonani G (1997) A pervasive millennial-scale cycle in North Atlantic Holocene and glacial climates. Science 278:1257-1266

Bond G, Kromer B, Beer J, Muscheler R, Evans MN, Showers W, Hoffmann S, Lotti-Bond R, Hajdas I, Bonani G (2001) Persistent solar influence on North Atlantic climate during the Holocene. Science 294:2130-2136

Böning P, Bard E, Rose J (2007) Toward direct, micron-scale XRF elemental maps and quantitative profiles of wet marine sediments. Geochem Geophys Geosyst 8:Q05004. https://doi.org/10.1029/2006GC001480

Chagué C, Cope J, Kilroy C, Jacobsen G, Zawadzki A, Wong H (2020) A 7300 year record of environmental changes in a coastal wetland (Moawhitu), New Zealand, and evidence for catastrophic overwash (tsunami?). Sediment Geol 407:105746

Chagué-Goff C (2010) Chemical signatures of palaeotsunamis: a forgotten proxy? Mar Geol 271:67-71

Chagué C, Sugawara D, Goto K, Goff J, Dudley W, Gadd P (2018) Geological evidence and sediment transport modeling for the 1946 and 1960 tsunamis in Shinmachi, Hilo, Hawaii. Sediment Geol 364:319-333

Chagué-Goff C, Goff J (1999) Geochemical and sedimentological signature of catastrophic saltwater inundations (tsunami), New Zealand. Quat Australas 17:38-48

Chagué-Goff C, Dawson S, Goff J, Zachariasen J, Berryman K, Garnett D, Waldron H, Mildenhall D (2002) A tsunami (ca. 6300 years BP) and other Holocene environmental changes, northern Hawke's Bay. NZ Sediment Geol 150:89-102

Chagué-Goff C, Andrew A, Szczuciński W, Goff J, Nishimura Y (2012a) Geochemical signatures up to the maximum inundation of the 2011 Tohokuoki tsunami-implications for the 869AD Jogan and other palaeotsunamis. Sediment Geol 282:65-77

Chagué-Goff C, Niedzielski P, Wong HKY, Szczuciński W, Sugawara D, Goff J (2012b) Environmental impact assessment of the 2011 Tohoku-oki tsunami on the Sendai Plain. Sediment Geol 282:175-187

Chagué-Goff C, Goff J, Wong HKY, Cisternas M (2015) Insights from geochemistry and diatoms to characterise a tsunami's deposit and maximum inundation limit. Mar Geol 359:22-34

Chagué-Goff C, Szczuciński W, Shinozaki T (2017) Applications of geochemistry in tsunami research: a review. Earth-Sci Rev 165:203-244

Chandrasekharan H, Sarangi A, Nagarajan M, Singh VP, Rao DUM, Stalin P, Natarajan K, Chandrasekaran B, Anbazhagan S (2008) Variability of soil-water quality due to Tsunami-2004 in the coastal belt of Nagapattinam district, Tamilnadu. J Environ Managem 89:63-72. https://doi.org/10.1016/j.jenvm an.2007.01.051

Chawchai S, Kylander ME, Chabangborn A, Löwemark L, Wohlfarth B (2016) Testing commonly used $X$-ray fluorescence core scanning-based proxies for organic-rich lake sediments and peat. Boreas 45:180-189

Costa PJM, Andrade C, Freitas M, Oliveira M, Lopes V, Dawson A, Moreno J, Fatela F, Jouanneau J-M (2012) A tsunami record in the sedimentary archive of the central Algarve coast, Portugal: characterizing sediment, reconstructing sources and inundation paths. Holocene 22:899-914

Croudace IW, Rindby A, Rothwell RG (2006) ITRAX: description and evaluation of a new multi-function X-ray core scanner. In: Rothwell RG (ed) 
New Techniques in Sediment Core Analysis, Special Publication, vol 267. Geological Society, London, pp 51-63

Cuven S, Paris R, Falvard S, Miot-Noirault E, Benbakkar M, Schneider J-L, Billy I (2013) High-resolution analysis of a tsunami deposit: case-study from the 1755 Lisbon tsunami in southwestern Spain. Mar Geol 337:98-111

Dominey-Howes DTM, Humphreys GS, Hesse PP (2006) Tsunami and palaeotsunami depositional signatures and their potential value in understanding the late-Holocene tsunami record. Holocene 16(8):1095-1107

Fruergaard M, Piasecki S, Johannessen PN, Noe-Nygaard N, Andersen TJ, Pejrup M, Nielsen LH (2015) Tsunami propagation over a wide, shallow continental shelf caused by the Storegga slide, southeastern North Sea, Denmark. Geology 43:1047-1050

Goff J, Chagué-Goff C, Nichol S, Jaffe B, Dale D-H (2012) Progress in palaeotsunami research. Sediment Geol 243-244:70-88

Goto K, Chagué-Goff C, Fujino S, Goff J, Jaffe B, Nishimura Y, Richmond B, Sugawara D, Szczuciński W, Tappin DR, Witter RC, Yulianto E (2011) New insights of tsunami hazard from the 2011 Tohoku-oki event. Mar Geol 290:46-50

Hennekam R, de Lange G (2012) X-ray fluorescence core scanning of wet marine sediments: methods to improve quality and reproducibility of high-resolution paleoenvironmental records. Limnol Oceanogr: Methods 10:991-1003

Ikehara K, Irino T, Usami K, Jenkins R, Omurad A, Ashi J (2014) Possible submarine tsunami deposits on the outer shelf of Sendai Bay, Japan resulting from the 2011 earthquake and tsunami off the Pacific coast of Tohoku. Mar Geol 358:120-127

Jansen JHF, Van der Gaast SJ, Koster B, Vaars AJ (1998) CORTEX, a shipboard XRF-scanner for element analyses in split sediment cores. Mar Geol 151:143-153

Judd K, Chagué-Goff C, Goff J, Gadd P, Zawadzki A, Fierro D (2017) Multi-proxy evidence for small historical tsunamis leaving little or no sedimentary record. Mar Geol 385:204-215

Komai T, Kawabe Y, Hara J, Sakamoto Y, Zhang M (2012) Geochemical survey of tsunami sediments and transport of toxic elements from offshore environment-Urgent investigation for Earthquake March 11, 2011. In: Proceedings of the Twenty-second (2012) International Offshore and Polar Engineering Conference. International Society of Offshore and Polar Engineers (ISOPE), Rhodes, Greece, pp 49-53, 17-22 June 2012.

Kumagai H (1999) Tsunami deposits of large earthquakes along the Nankai Trough: investigation around Hamana Lake in central Japan. J Geogr 108:424-432 (in Japanese with English abstract)

Kuwatani T, Nagata K, Okada M, Watanabe T, Ogawa Y, Komai T, Tsuchiya N (2014) Machine-learning techniques for geochemical discrimination of 2011 Tohoku tsunami deposits. Sci Rep 4:7077. https://doi.org/10.1038/ srep07077

Minoura K, Nakaya S (1991) Traces of tsunami preserved in inter-tidal lacustrine and marsh deposits: some examples from Northeast Japan. J Geol 99(2):265-287

Moreira S, Costa PJM, Andrade C, Lira CP, Freitas MG, Oliveira MA, Reichart G-」 (2017) High resolution geochemical and grain-size analysis of the AD 1755 tsunami deposit: insights into the inland extent and inundation phases. Mar Geol 390:94-105

Morton RA, Gelfenbaum G, Jaffe BE (2007) Physical criteria for distinguishing sandy tsunami and storm deposits using modern examples. Sediment Geol 200:184-207

Nakamura M, Ikeda Y, Matsumoto A, Maki H, Arakawa H (2018) Distribution of hydrocarbons in seabed derived from tsunami-spilled oil in Kesennuma Bay, Japan. Mar Pollut Bull 128:115-125

Nakaya T, Tanji H, Kiri H, Hamada H (2010) Developing a salt-removal plan to remedy tsunami-caused salinity damage to farmlands: case study for an area in Southern Thailand. JARQ 44(2):159-165

Namegaya Y, Satake K (2014) Reexamination of the A.D. 869 Jogan earthquake size from tsunami deposit distribution, simulated flow depth, and velocity. Geophys Res Lett 41:2297-2303. https://doi.org/10.1002/2013GL0586 78

Ota Y, Suzuki A, Yamaoka K, Nagao M, Tanaka Y, Irizuki T, Fujiwara O, Yoshioka K, Kawagata S, Kawano S, Nishimura O (2019) Sediments of Matsushima Bay, Northeastern Japan: insights gained from 5 years of sedimentological analysis following the 2011 Tohoku Earthquake-Tsunami. Geochem Geophy Geosy 20:3913-3927
Parfitt RL, Giltrap DJ, Whitton JS (1995) Contribution of organic matter and clay minerals to the cation exchange capacity of soils. Commun Soil Sci Plant Anal 26(9 \& 10):1343-1355

Pouzet P, Robin M, Decaulne A, Gruchet B, Maanan M (2018) Sedimentologi$\mathrm{cal}$ and dendrochronological indicators of coastal storm risk in western France. Ecol Indic 90:401-415

Richter TO, Van der Gaast S, Koster B, Vaars A, Gieles R, de Stigter H, de Haas $H$, van Weering TCE (2006) The Avaatech XRF core scanner: technical description and applications to NE Atlantic sediments. In: Rothwell RG (ed) New techniques in sediment core analysis, special publication, vol 267. Geological Society, London, pp 39-50

Robertson GP, Sollins P, Ellis BG, Lajtha K (1999) Exchangeable ions, pH, and cation exchange capacity. In: Robertoson GP, Coleman DC, Bledsoe CS, Sollins P (eds) Standard soil methods for long-term ecological research. Oxford University Press, New York, pp 106-114

Sakuna D, Szczuciński W, Feldens P, Schwarzer K, Khokiattiwong S (2012) Sedimentary deposits left by the 2004 Indian Ocean tsunami on the inner continental shelf offshore of Khao Lak, Andaman Sea (Thailand). Earth Planets Space 64:931-943

Shinozaki T, Fujino S, Ikehara M, Sawai Y, Tamura T, Goto K, Sugawara D, Abe T (2015) Marine biomarkers deposited on coastal land by the 2011 Tohokuoki tsunami. Nat Hazards 77:445-460

Shinozaki T, Sawai Y, Hara J, Ikehara M, Matsumoto D, Tanigawa K (2016) Geochemical characteristics of deposits from the 2011 Tohoku-oki tsunami at Hasunuma, Kujukuri coastal plain, Japan. Isl Arc 25:350-368

Shinozaki T, Sawai Y, Ito K, Hara J, Matsumoto D, Tanigawa K, Pilarczyk JE (2020) Recent and historical tsunami deposits from Lake Tokotan, eastern Hokkaido, Japan, inferred from non-destructive, grain size, and radioactive cesium analyses. Nat Hazards 103:713-730

Srinivasalu S, Jonathan MP, Thangadurai N, Ram-Mohan V (2010) A study on pre-and post-tsunami shallow deposits off SE coast of India from the 2004 Indian Ocean tsunami: a geochemical approach. Nat Hazards 52:391-401

Stein R, Fahl L (2000) Holocene accumulation of organic carbon at the Laptev Sea continental margin (Arctic Ocean): sources, pathways, and sinks. GeoMar Lett 20:27-36

Szczuciński W (2020) Postdepositional changes to tsunami deposits and their preservation potential. In: Engel M, Pilarczyk J, May SM, Brill D, Garrett E (eds) Geological records of tsunamis and other extreme waves, 1 st edn. Elsevier, Amsterdam, pp 443-469

Szczuciński W, Niedzielski P, Kozak L, Frankowski M, Zioła A, Lorenc S (2007) Effects of rainy season on mobilization of contaminants from tsunam deposits left in a coastal zone of Thailand by the 26 December 2004 tsunami. Environ Geol 53:253-264

Szczuciński W, Kokociński M, Rzeszewski M, Chagué-Goff C, Cachão M, Goto K, Sugawara D (2012) Sediment sources and sedimentation processes of 2011 Tohoku-oki tsunami deposits on the Sendai Plain, Japan -Insights from diatoms, nanoliths and grain size distribution. Sediment Geol 282:40-56

Szczuciński W, Pawłowska J, Lejzerowicz F, Nishimura Y, Kokociński M, Majewski W, Nakamura Y, Pawlowski J (2016) Ancient sedimentary DNA reveals past tsunami deposits. Mar Geol 381:29-33

Tjallingii R, Röhl U, Kölling M, Bickert T (2007) Influence of the water content on X-ray fluorescence core-scanning measurements in soft marine sediments. Geochem Geophy Geosy 8:Q02004. https://doi. org/10.1029/2006GC001393

Toyofuku T, Duros P, Fontanier C, Mamo B, Bichon S, Buscail R, Chabaud G, Deflandre B, Goubet S, Grémare A, Menniti C, Fujii M, Kawamura K, Koho KA, Noda A, Namegaya Y, Oguri K, Radakovitch O, Murayama M, de Nooijer L, Kurasawa A, Ohkawara N, Okutani T, Sakaguchi A, Jorissen F, Reichart GJ, Kitazato H (2014) Unexpected biotic resilience on the Japanese seafloor caused by the 2011 Tōhoku-Oki tsunami. Sci Rep 4:7517. https://doi. org/10.1038/srep07517

Ünlü S, Alpar B, Altınok Y, Özer N (2012) Rapid coastal changes and tsunami impacts at the Patara Harbour (Turkey). Proceedings of the International Conference. Land-Sea Interaction in the Coastal Zone LANDSI-2012:411-418.

Watanabe T, Tsuchiya N, Yamasaki S, Sawai Y, Hosoda N, Nara FW, Nakamura T, Komai T (2020) A geochemical approach for identifying marine incursions: implications for tsunami geology on the Pacific coast of northeast 
Japan. Appl Geochem 118:104644. https://doi.org/10.1016/j.apgeo chem.2020.104644

Weltje GJ, Tjallingii R (2008) Calibration of XRF core scanners for quantitative geochemical logging of sediment cores: Theory and application. Earth Planet Sci Lett 274:423-438

Yoshii T, Imamura M, Matsuyama M, Koshimura S, Matsuoka M, Mas E, Jimenez C (2013) Salinity in soils and tsunami deposits in areas affected by the 2010 Chile and the 2011 Japan tsunamis. Pure Appl Geophys 170:1047-1066

Zhao D, Wan S, Toucanne S, Clift PD, Tada R, Révillon S, Kubota Y, Zheng X, Yu Z, Huang J, Jiang H, Xu Z, Shi X, Li A (2017) Distinct control mechanism of fine-grained sediments from yellow river and Kyushu supply in the northern Okinawa trough since the last glacial. Geochem Geophy Geosy 18:2949-2969. https://doi.org/10.1002/2016GC006764

\section{Publisher's Note}

Springer Nature remains neutral with regard to jurisdictional claims in published maps and institutional affiliations.

\section{Submit your manuscript to a SpringerOpen ${ }^{\circ}$ journal and benefit from:}

- Convenient online submission

- Rigorous peer review

- Open access: articles freely available online

- High visibility within the field

- Retaining the copyright to your article

Submit your next manuscript at $\boldsymbol{\nabla}$ springeropen.com 